\title{
La narrativa de Edgardo Rivera Martínez: Personificaciones míticas en mundos prosaicos
}

\author{
Carlos Schwalb Tola \\ Emory University \\ carlosschwalb@yahoo.com \\ $\&$
}

\section{Resumen}

Las personificaciones mágicas y míticas en la narrativa corta de Edgardo Rivera Martínez son figuras enigmáticas de identidades inciertas y rasgos contradictorios. Constituyen símbolos que ilustran el complejo proceso de la creación artística del autor, un entretejido indiscernible de aspectos culturales, existenciales y psicológicos.

Palabras claves: Personificaciones míticas, símbolos, creación artística, Identidad.

\begin{abstract}
The magical and mythical personifications in Edgardo Rivera Martínez short stories are enigmatic figures of uncertain identities and contradictory features. They are symbols that depict the complex process of the artistic creation of the author, an indiscernible interweaving of the cultural, the existential and the psychological.

Key words: Mythical personifications, Symbols, Artistic creation, Identity.
\end{abstract}

Recibido: 12/10/2015 Aceptado 15/11/2015 
La narrativa corta de Edgardo Rivera Martínez está poblada por personificaciones mágicas y míticas -ángeles, demonios, fantasmas y "entes" diversos de la naturaleza-, cuya presencia recurrente en sus cuentos invita a la reflexión crítica: ¿Quiénes son? ¿Qué los caracteriza? ¿Qué función cumplen en el texto?

Destaca en primer término el hecho de que muchas de estas personificaciones no tengan una identidad, un propósito y un origen conocidos. Del ángel de Ocongate, en el cuento del mismo nombre, se nos dice que es una "apagada sombra" (Rivera Martínez 1999: 19) que carece de memoria y que "no sabrá nunca razón de su caída" (22), motivo por el cual deambula sin descanso por la desolada puna. Ninguno de los habitantes de los pueblos por los que pasa sabe su nombre ni su procedencia: “¿Quién será? ¿De qué baile será esa ropa? ¿Dónde habrá danzado?”, “Cómo te llamas? ¿Cuál es tu pueblo?” (19), se preguntan todos ellos sin obtener respuesta del protagonista, porque él mismo no la tiene. Igualmente, Amaru, en el cuento del mismo nombre, posee una identidad y un origen inciertos. Al principio de su largo y enfebrecido soliloquio confiesa que surge de la obscuridad y que solo es una sombra en la penumbra (107); hacia el final del mismo su condición no ha variado, y se resalta el hecho de que solo es una "onírica subjetividad" (112). Al igual que el ángel de Ocongate, su soliloquio consiste en una indagación sin término sobre su naturaleza, su origen y su destino. Aunque tiene raíces míticas (Los amarus son serpientes aladas que habitan en los lagos andinos), el narrador conjetura que sus arquetipos estuvieron en el Pamir y el Éufrates; no obstante su condición inmortal, su destino parece ser el de cualquier criatura mortal: "En polvo invisible se convertirá mi cuerpo" (112). Por otra parte, Amaru manifiesta un vínculo entrañable con la naturaleza: "¿No se nota ya en mi rostro una dureza de diorita? Se diría, incluso, que exhalo un hálito de ríos y de bosques” (112). A caballo entre una patria lejana e ignota y otra conocida y próxima, entre una naturaleza inmortal y otra mortal, entre una existencia onírica y una que se emparienta con la naturaleza, la identidad de Amaru resulta enigmática para el lector. En el cuento "Enigma del árbol" tampoco queda clara la identidad del misterioso arbolillo que un día aparece en el jardín de la casa de Anastas, el protagonista del relato. Se trata de un "árbol sin nombre", de una especie desconocida, de la que ni el herbolario más experto de Ayacucho puede dar razón (52). Anastas conjetura que su origen podría estar en Armenia, la patria de su abuelo, de donde la semilla habría llegado por azar; pero también podría estar en regiones y tiempos remotos, como Anatolia, Mesopotamia o Persia. Más que un árbol cualquiera da la impresión de ser, en opinión del narradorprotagonista, "una presencia tan plena de vida y tan impregnada de misterio y de poesía" (51), es decir, una personificación mágica que establecerá a lo largo del relato un vínculo simbiótico con los habitantes de la casa. En el cuento 
"Una flor en la plaza de la Buena Muerte", unos peces disecados conforman "una fauna fantasmal y sin nombre" (256) que reviven mágicamente ante la mirada aturdida del protagonista. Este no está seguro de si estas apariciones se deben a un estado alterado de su conciencia o si poseen vida propia: “ ¿No habría sido víctima de una alucinación? ¿Eran causas físicas, solamente físicas, las que desencadenaban aquel fenómeno?" (257). Preguntas sobre la identidad de los peces y, en un plano más amplio, sobre la naturaleza de lo real que constituyen el leitmotiv del cuento. ${ }^{1}$

Además de la problemática identidad de las personificaciones míticas del autor, llama la atención también su entorno, la atmósfera que los rodea y los espacios que habitan. Permean estos cuentos imágenes asociadas con lo ruinoso, la desolación, la corrupción y la muerte. El ángel de Ocongate viste harapos y habita en una capilla en ruinas en la puna desolada e inmensa (19). Amaru ha surgido como una "emanación del tiempo y la ruina" (107), y anuncia su próxima muerte en una tormenta "que pondrá fin a todo" (110). En "Enigma del árbol", el arbolillo que al principio posee una plena de vida, va adquiriendo con el paso del tiempo un aura de finitud y tristeza, lo cual hace decir a la esposa del protagonista que es un "árbol de muerte" (58). Los peces disecados en la plazuela de la Buena Muerte son piezas carcomidas por el moho y tienen "una mustia apariencia de vida" (255); del mismo modo, el protagonista no es un hombre vital ni alegre, sino taciturno, y la vida que lleva está estrechamente vinculada con el dolor y la muerte: trabaja entre colgaduras, crucifijos y ataúdes en una funeraria de nombre irónico: "El Triunfo". También la plazuela que suele visitar algunas noches irradia un halo de ruina, lo mismo que la iglesia que la preside, y ambas se hallan sumergidas en una niebla densa y permanente.

Por lo dicho hasta aquí podría interpretarse que la narrativa del autor-me refiero a los cuentos citados y a otros en los que aparecen personificaciones semejantes (cf. nota 1)- refleja una poética de la pérdida o del duelo. Poética que por un lado revela una sensibilidad melancólica, herida, y por otro, en un plano gnoseológico, puede interpretarse como un indicio del debilitamiento o la agonía de la cosmovisión mágico-mítica andina -pero no solo andina- como modo de conocimiento de la realidad. En efecto, si estas criaturas han perdido la memoria de sus orígenes, si visten harapos y habitan en territorios desolados, sombríos o ruinosos, puede inferirse que encarnan simbólicamente dicho

1 Por razones de espacio, y para no cansar al lector con un análisis exhaustivo de estas personificaciones mágico-míticas, me he limitado a analizar cuatro cuentos del autor. Otros cuentos que también pueden prestarse a un análisis parecido son, entre otros: "El Unicornio", "El organillero", "El visitante”, "Encuentro frente al mar", "Aparición”, "Leda en el desierto”, "Enunciación”, "Encuentro frente al mar". 
debilitamiento y agonía. Y, sin embargo, una conclusión así pasaría por alto un aspecto de signo opuesto en la narrativa del autor, que más bien celebra la vida, la regeneración, el renacimiento, y que, en un plano gnoseológico, testimonia la plena vigencia de la magia y el mito.

En el cuento Amaru la mítica serpiente andina agoniza, pero al mismo tiempo anuncia su futuro renacimiento: "alguna vez, en una noche muy distante, otra sierpe se levantará de mis cenizas" (112). Asimismo, a pesar vivir en la oscuridad y de se parte de esta ("sombra soy en la penumbra"), Amaru trabaja en una ambiciosa obra musical de inspiración panteísta que recogerá "los timbres y el espíritu de antaras y sicuris" (111) y será una "alabanza del agua. Alegría de los puquios y de los lagos. Glaciares del Salcantay y el Ausangate y del Apurímac, el Yavarí, el Ucayali” (112). Parecido mensaje de regeneración vital lo encontramos en el cuento "Una flor en la plaza de la Buena Muerte", en el que la imaginería relacionada con la corrupción y la muerte no impide que brote de esta la vida. Cuando el protagonista toca el vidrio de la vitrina con sus manos blancas y espectrales que irradian "un hálito de muerte" (260), los peces reviven y escapan de la vitrina hacia la plaza, iniciando una danza vital de carácter dionisíaco que hace eco en el alma del protagonista y en su entorno. De allí que el narrador diga que se trata, paradójicamente, de una "vida que se alimentaba de muerte, mas no por ello menos vida" (260). En un plano gnoseológico, lo mágico impone su verdad al final del cuento se encuentra en la mano del protagonista muerto "una flor roja y opulenta, que alguien reconoció después como una flor amazónica" (261). Este hallazgo hace suponer que se trata de la materialización de los peces fantasmales de procedencia amazónica que esa noche han danzado como "una floración en que se juntaban la noche, la niebla y el vaho de una floresta imposible" (261). La existencia física de esta flor que solo existía en una dimensión sobrenatural responde implícitamente a la pregunta inicial del protagonista sobre la naturaleza de los peces disecados que reviven en la vitrina de la plaza: estos no son producto de una alucinación; son reales y tienen vida propia.

Se ha dicho repetidas veces que la obra de Rivera Martínez constituye un entretejido de lo andino y lo occidental. Y se ha dicho también que este entretejido no es conflictivo sino feliz, armónico. Esta lectura es sin duda válida cuando se refiere a las novelas del autor, sobre todo a "País de Jauja", como además refrenda este: "esos dos mundos, el andino y el occidental y de la modernidad, no se enfrentan, no colisionan, sino que en el caso del protagonista se entreteje progresivamente, no sin algunas preguntas y perplejidades, y se amalgaman" (Rivera Martínez 1996: 28). Pero en la narrativa corta del autor vemos un entretejido no solo de dos culturas, sino también de dos 
fuerzas psíquicas -lo erótico y lo tanático-; de dos sensibilidades -lo sombrío melancólico y lo luminoso vital-; de dos expectativas -una apocalíptica, otra utópica-; de dos formas de conocimiento de la realidad -una mágico-mítica, otra racional cartesiana. Entretejido que, además, las más de las veces, no es feliz ni armónico sino conflictivo. De allí que, desde un punto de vista crítico, sea necesario aproximarse a la narrativa corta del autor desde una perspectiva de interpretación que, sin excluir los aspectos culturales, intente ampliar el campo de su visión. De hecho, hay cuentos -en los que también aparecen estas personificaciones- que están ambientados en la costa y que poco o nada tienen que ver con las mitologías andinas y los encuentros o desencuentros culturales de lo andino con lo occidental moderno (Cf. "El visitante", "Encuentro frente al mar", "Aparición", "Leda en el desierto", "El organillero", etc.). El mismo autor ha mencionado a propósito de su cuento "Ángel de Ocongate" opinión que se puede hacer extensiva a otros cuentos suyos- que este trata de "la problemática de una identidad que a la luz del texto es a la vez metafísica, existencial y cultural" (27). En efecto, si las personificaciones mágico-míticas del autor ilustraran solo la problemática de la identidad cultural veríamos en ellos las marcas de un mestizaje, feliz o no, en su apariencia, su lenguaje, su cosmovisión; pero lo que vemos, ante todo, son enigmas. La pregunta por la identidad de estas personificaciones permanece abierta desde el principio hasta el fin de los relatos analizados, tanto para los protagonistas como para el lector. En este sentido la labor del crítico consiste, no en tratar de descifrar el enigma, sino en preguntarse por su razón de ser.

El autor ha señalado en varias ocasiones la necesidad de ampliar el rango de la pregunta por lo humano. A propósito de un artículo suyo sobre la novela, el psicoanálisis y la historia ha expuesto la necesidad de un "descubrimiento del hombre por el hombre mismo, pero no solo en su dimensión occidental sino universal" (Rivera Martínez 1996: 74). Esta universalidad incluye, por lo que se deduce de su artículo, aspectos históricos y, sobre todo, psíquicos no conscientes: "No estaría mal que los historiadores sumaran a la versación especializada, y a la cultura humanística, una apreciable información sobre aspectos no conscientes de la vida psíquica" (75). En el escenario de la vida psíquica ocurre un drama de impulsos o deseos contradictorios parecido al que representan los personajes de la ficción: "Desde entonces tuve muy presente que bajo la apariencia de la vida más luminosa y feliz, alienta siempre un mundo tenebroso, como ya puso en evidencia Nietzsche en el siglo pasado, con la oposición de lo apolíneo y de lo dionisiaco" (75). Incluso más adelante en el mismo artículo el autor señala explícitamente que los "fantasmas" de su ficción son proyecciones de sus afectos: "[los personajes que crea el narrador] acaso se convierten en fantasmas en los que el autor proyecta nuevamente sus afectos, 
en la relectura de su propia producción, en un proceso en espiral, que de algún modo se reproduce en el lector, en un ciclo sin término". (82-3). ¿No son los ángeles, demonios, fantasmas y demás personificaciones mágico-míticas de la naturaleza que hemos analizado aquí (y otros no analizados aquí) proyecciones de estos afectos?

Al hablar de sus fantasmas como "proyecciones de afectos" el autor subraya el origen intuitivo de estos. No son, pues, meras ilustraciones de una idea que los precede, sino que encarnan la intuición misma, en lo que esta tiene de difuminada y compleja. En este sentido hay que hablar de símbolos, no de alegorías, según la útil distinción de Benedetto Croce, que retoma Borges en uno de sus ensayos sobre el tema. Dice Croce: "Si el símbolo es concebido como inseparable de la intuición artística, es sinónimo de la intuición misma, que siempre tiene carácter ideal. Si el símbolo es concebido separable, si por un lado puede expresarse el símbolo y por otro la cosa simbolizada, se recae en el error intelectualista; el supuesto símbolo es la exposición de un concepto abstracto, es una alegoría, es ciencia, o arte que remeda la ciencia” (Borges 1974: 744). No se puede, pues, descifrar el enigma de las personificaciones del autor según conceptos que provengan de la cantera de la ciencia -de la sociología, la antropología cultural, la psicología- sin hacerles perder al mismo tiempo su carácter de símbolos en el sentido dado por Croce. El papel de la crítica consiste entonces, en mi opinión, en resaltar las recurrencias temáticas, los ecos o huellas culturales y psíquicas presentes en estas simbolizaciones, sin restarles mediante esta operación su carácter enigmático.

Kafka dijo a propósito de los mitos una frase que puede aplicarse a las personificaciones mágico-míticas de nuestro autor: "El mito intenta explicar lo inexplicable, y como tiene su origen en un motivo de verdad, debe finalizar nuevamente en lo inexplicable" (Kafka 1975: 83). Los fantasmas en estos cuentos intentan dar forma a lo inexplicable; pero finalizan nuevamente en lo inexplicable. Este movimiento de ida y vuelta, de la noche del mundo a la claridad del mito, y de vuelta a la noche del mundo es el doble trayecto que nos vemos obligados a transitar al leer los cuentos de Rivera Martínez. Pero, ¿no es la tarea de todo verdadero artista, de todo poeta, sacarnos de la oscuridad para luego devolvernos a ella?

\section{Referencias bibliográficas}

BORGES, Jorge Luis (1974). "De las Alegorías a las novelas". En: Obras Completas de Jorge Luis Borges. Buenos Aires: Emecé Editores, pp.744 46.

KAFKA, FRANZ (1975). “Prometeo”. En: La Muralla china. Buenos Aires: Alianza Editorial, p. 83. 
La narrativa de Edgardo Rivera Martínez: Personificaciones míticas en mundos prosaicos

RIVERA MARTÍNEZ, Edgardo (1999). Cuentos completos. Lima: Alfaguara.

RIVERA MARTÍNEZ, Egardo (1996) “Novela, el psicoanálisis y la historia. Un testimonio y algunas reflexiones”. En: Edgardo Rivera Martínez: Nuevas lecturas. César Ferreira, (editor). Lima: Fondo Editorial UNMSM., pp. 73-85. 